\title{
Analysis of Amisulpride in Human Plasma by SPE and LC with Fluorescence Detection
}

\author{
Illia V. Kudris • Nona N. Skakun • Irina N. Orlova • \\ Victoria V. Libina $\cdot$ Artem U. Kulikov
}

Received: 8 July 2010/Revised: 22 September 2010/Accepted: 19 October 2010/Published online: 8 January 2011

(C) The Author(s) 2011. This article is published with open access at Springerlink.com

\begin{abstract}
A rapid, precise, accurate, and selective highperformance liquid chromatographic method with fluorescence detection has been validated and used for analysis of amisulpride in human plasma after a simple solid-phase extraction procedure. Compounds were separated on a $\mathrm{CN}$ column with $0.03 \mathrm{M}$ potassium dihydrogen phosphate $(\mathrm{pH}$ 6.5)-acetonitrile 65:35 (v/v) as mobile phase. Fluorescence detection was performed at excitation and emission wavelengths of 274 and $370 \mathrm{~nm}$, respectively. Calibration plots were linear over the concentration range $10-1,000 \mathrm{ng} \mathrm{mL}^{-1}$ in human plasma, and the lower limit of quantification was $10 \mathrm{ng} \mathrm{mL}^{-1}$. Accuracy was between 0.4 and $6.4 \%$ and precision was between 3.1 and $7.5 \%$. Amisulpride was sufficiently stable through three freeze-thaw cycles, during storage for $6 \mathrm{~h}$ at room temperature, and for 2 months at $-22{ }^{\circ} \mathrm{C}$. The method is suitable for the analysis of clinical samples from pharmacokinetic studies.
\end{abstract}

Keywords Column liquid chromatography · Amisulpride · Validation · Solid-phase extraction . Pharmacokinetic study

I. V. Kudris · N. N. Skakun - I. N. Orlova · V. V. Libina Laboratory of Pharmacokinetics, State Pharmacological Center, Astronomicheskaya Street 33, Kharkov 61085, Ukraine

\section{A. U. Kulikov ( $\square)$}

Laboratory of Pharmacopoeial Analysis,

Scientific and Expert Pharmacopoeial Centre,

Astronomicheskaya Street 33, Kharkov 61085, Ukraine

e-mail: kulikov@phukr.kharkov.ua

\section{Introduction}

Amisulpride ((R,S)-4-amino- $N$-[(1-ethylpyrrolidin-2-yl)methyl]-5-ethylsulphonyl-2-methoxybenzamide) is a 2-methoxybenzamide derivative chemically related to sulpiride. It is an antagonist of dopamine $\mathrm{D}_{2}$ and $\mathrm{D}_{3}$ receptors [1]. It is effective as an antidysthymic, antischizophrenic, or antipsychotic drug, depending on the dose: $50-100 \mathrm{mg}$ for treatment of dysthymic disorders [2, 3], over $200 \mathrm{mg}$ for treatment of negative symptoms in schizophrenic patients, and over $600 \mathrm{mg}$ for psychotic disorders [4].

Amisulpride is rapidly absorbed, with an absolute bioavailability of approximately $50 \%$ and a biphasic absorption profile $[5,6]$. Two distinct plasma concentration peaks are usually observed approximately 1 and $3-4 \mathrm{~h}\left(T_{\max }\right)$ after administration. The protein binding of this drug is approximately $17 \%$ and the average amisulpride elimination half-life from plasma, after oral administration, is approximately 11-12 h [5, 6]. Low metabolism (approx. $5 \%$ of the administered dose) is a characteristic of amisulpride, and unmodified drug is primarily excreted in the urine (50\% of an intravenous dose is excreted via the urine, of which $90 \%$ is eliminated in the first $24 \mathrm{~h}$ ) $[4,5]$.

Several methods have been used for analysis of amisulpride in human plasma, including gas chromatography [7], radioreceptor assay [8], and high-performance liquid chromatography (LC) with UV [9-11], mass spectrometric $[12,13]$, or fluorescence $[14,15]$ detection.

Gschwend et al. [13] reported a sensitive LC method with mass spectrometric detection after liquid-liquid extraction (diisopropyl ether-dichloromethane 1:1 (v/v)); a low limit of quantification (LLOQ) of $0.5 \mathrm{ng} \mathrm{mL}^{-1}$ amisulpride was achieved. Kirchherr et al. [12] used another LC-MS method for analysis of antidepressants and achieved an LLOQ of $28 \mathrm{ng} \mathrm{mL}^{-1}$ for amisulpride. 
Frahnert et al. [9] used solid-phase extraction for isolation of amisulpride from plasma. Chromatographic separation on a Nucleosil 100-Protect 1 column was followed by UV detection. Response was a linear function of concentration over the range $10-1,000 \mathrm{ng} \mathrm{mL}^{-1}$.

A fully automated chromatographic method including on-line blood serum or plasma clean-up, isocratic LC, and spectrophotometric detection was reported by Sachse et al. [10]. Plasma or serum was cleaned on a silica $\mathrm{CN}$ $(10 \times 4.0 \mathrm{~mm}$ i.d., $20-\mu \mathrm{m}$ particle $)$ column and further separation was performed on a LiChrospher $\mathrm{CN}$ column. The limit of detection was $10 \mathrm{ng} \mathrm{mL}^{-1}$ and the linear range $10-600 \mathrm{ng} \mathrm{mL}^{-1}$.

Malavasi et al. [14] used both liquid-liquid extraction and solid-phase extraction for isolation of amisulpride from human plasma. LC separation was performed on a Hypersil $\mathrm{C}_{18}$ BDS column. Fluorescence detection with excitation and emission wavelengths of 280 and $370 \mathrm{~nm}$, respectively, resulted in a limit of quantification of $0.5 \mathrm{ng} \mathrm{mL}^{-1}$ and a calibration range of $0.5-640 \mathrm{ng} \mathrm{mL}^{-1}$.

The objective of this work was to develop and validate a rapid and sensitive LC method with simple sample preparation for analysis of amisulpride in human plasma, and to use it in a randomized cross-over bioequivalence study after oral administration of two different amisulpride preparations $(200 \mathrm{mg})$ to 18 healthy volunteers. Fluorescence detection was chosen as more sensitive and specific than UV detection. Most existing methods for analysis of amisulpride in human plasma have an upper limit of quantification in the range $600-640 \mathrm{ng} \mathrm{mL}^{-1}$. This is suitable for study of pharmacokinetics after oral administration of $50 \mathrm{mg}$ amisulpride. After an oral dose of $200 \mathrm{mg}$ the expected $C_{\max }$ is $>500 \mathrm{ng} \mathrm{mL}^{-1}$ with a standard deviation of approximately $200 \mathrm{ng} \mathrm{mL}^{-1}$, and thus the upper limit of quantification should be not less than $850 \mathrm{ng} \mathrm{mL}^{-1}$. Our method includes a simple singlestage SPE procedure (loading-washing-collection). The method was validated in accordance with FDA guidelines [16] to assess its selectivity, sensitivity, accuracy, and precision.

\section{Experimental}

Chemicals, Reagents, and Solutions

The amisulpride standard was a European Pharmacopoeia standard (purity 99.9\%; Council of Europe, European Directorate for the Quality of Medicines and Health Care, Strasbourg, France). Metoclopramide hydrochloride (4-amino-5-chloro- $N$-[(2-diethylamino)ethyl]-2-methoxybenzamide hydrochloride; purity $99.73 \%$ ), used as internal standard (IS), was purchased from Ipca Laboratories<smiles>CCN1CCCC1CN=NC(=O)c1cc(S(=O)(=O)CC)c(N)cc1OC</smiles><smiles>CCN(CC)CCNC(=O)c1cc(Cl)c(N)cc1OCC(C)C</smiles>

Fig. 1 The chemical structures of amisulpride and metoclopramide (IS)

(Mumbai, India). The chemical structures of both substances are shown in Fig. 1.

Methanol and acetonitrile were HPLC-grade (SigmaAldrich, St Louis, MO, USA). Triethylamine, orthophosphoric acid (85\%), and potassium dihydrogen phosphate were analytical grade (Fluka, Buchs, Switzerland). Doubledistilled water purified with a Milli-Q5 system (Millipore, Bedford, MA, USA) was used in all experiments.

Human plasma was obtained from the Kharkov Center of Blood Service (Kharkov, Ukraine).

Oasis HLB solid-phase extraction cartridges $(1 \mathrm{cc}$, $30 \mathrm{mg}$; Waters, Milford, MA, USA) were used for sample preparation.

Amisulpride stock standard solution $\left(1 \mathrm{mg} \mathrm{mL}^{-1}\right)$ was prepared in methanol. Working solutions $(1.0,2.5,3.0,5.0$, $10,25,30,50,75,90$, and $100 \mu \mathrm{g} \mathrm{mL}^{-1}$ ) were prepared by dilution of the stock solution with pure water. These amisulpride working solutions were used for preparation of validation plasma samples (standard calibration samples and quality-control samples) and amisulpride working standard solutions.

Amisulpride working standard solutions were prepared at concentrations of $20,50,100,200,500,1,000,1,500$, and $2,000 \mathrm{ng} \mathrm{mL}^{-1}$, by dilution of $200 \mu \mathrm{L}$ of the appropriate amisulpride working solution to $10 \mathrm{~mL}$ with wateracetonitrile 75:25 $(v / v)$. Amisulpride working standard solutions were used for assessment of the linearity of detector response.

Internal standard (metoclopramide) solution $\left(1 \mathrm{mg} \mathrm{mL}^{-1}\right)$ was prepared in pure water and diluted to $100 \mu \mathrm{g} \mathrm{mL}^{-1}$ with pure water.

To prepare calibration standards, $2 \mathrm{~mL}$ human plasma was mixed with $20 \mu \mathrm{L}$ of the appropriate amisulpride working solution to furnish concentrations of $10,25,50$, $100,250,500,750$, and $1,000 \mathrm{ng} \mathrm{mL}^{-1}$. The IS solution $\left(100 \mu \mathrm{g} \mathrm{mL}^{-1}, 15 \mu \mathrm{L}\right)$ was added to $1.5 \mathrm{~mL}$ of the 
corresponding calibration standard and the procedure for sample preparation, described below, was carried out.

To prepare quality-control samples $250 \mu \mathrm{L}$ of the appropriate amisulpride working solution was diluted with $25 \mathrm{~mL}$ human plasma to furnish concentrations of 30,300 ,

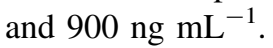

To prepare amisulpride samples with concentrations above the calibration range $\left(1,800 \mathrm{ng} \mathrm{mL}^{-1}\right), 500 \mu \mathrm{L}$ amisulpride working solution (concentration $90 \mu \mathrm{g} \mathrm{mL}^{-1}$ ) was diluted with $25 \mathrm{~mL}$ human plasma. This solution was used to test the integrity of the dilution procedure.

IS solution (100 $\left.\mathrm{g} \mathrm{mL}^{-1}, 15 \mu \mathrm{L}\right)$ was added to $1.5 \mathrm{~mL}$ of the corresponding validation sample and the procedure for sample preparation, described below, was carried out.

\section{Sample Preparation}

Frozen plasma samples were thawed at ambient temperature $\left(20 \pm 2{ }^{\circ} \mathrm{C}\right)$ and vortex-mixed for $30 \mathrm{~s}$. Plasma $(1.5 \mathrm{~mL})$ was placed in a plastic tube, $15 \mu \mathrm{L}$ IS solution $\left(100 \mu \mathrm{g} \mathrm{mL}^{-1}\right)$ was added, and vortex mixing was performed for $30 \mathrm{~s}$. Samples were centrifuged at $11,000 \mathrm{~g}$ for $15 \mathrm{~min}$. After centrifugation, $1.0 \mathrm{~mL}$ of the supernatant was loaded on to a previously activated SPE cartridge. The cartridge was washed with $1 \mathrm{~mL}$ pure water then the amisulpride and metoclopramide were eluted with $1.0 \mathrm{~mL}$ methanol. The eluent was collected in a polypropylene tube and evaporated to dryness under vacuum at $58{ }^{\circ} \mathrm{C}$. The residue was reconstituted with $500 \mu \mathrm{L}$ water-acetonitrile mixture 75:25 $(v / v)$ and the solution was vortex-mixed and analyzed.

\section{Instrumentation and Chromatographic Conditions}

HPLC was performed with a Perkin Elmer (Shelton, USA) series 200 system consisting of vacuum degasser, gradient pump, thermostatic autosampler, column oven, fluorescence detector, diode-array detector, and network chromatographic interface (NCI 900). TotalChrom ver. 6.0 software (Perkin Elmer) was used for acquisition and processing of chromatographic data.

Chromatographic separation was performed at $35^{\circ} \mathrm{C}$ on a $250 \times 4.6 \mathrm{~mm}$ i.d., particle size $5 \mu \mathrm{m}$, Zorbax SB-CN analytical column (Agilent Technologies, USA) with a $12.5 \times 4.6 \mathrm{~mm}$ i.d., particle size $5 \mu \mathrm{m}$, Zorbax SB-CN guard column (Agilent). The mobile phase was $0.03 \mathrm{M}$ phosphate buffer ( $\mathrm{pH}$ 6.5)-acetonitrile 65:35 ( $/ / v)$. The $0.03 \mathrm{M}$ phosphate buffer solution ( $\mathrm{pH}$ 6.5) was prepared by dissolving $4.1 \mathrm{~g}$ potassium dihydrogen phosphate in $950 \mathrm{~mL}$ pure water, adjusting to $\mathrm{pH} 6.5 \pm 0.1$ with triethylamine, and diluting to $1,000 \mathrm{~mL}$ with pure water. The mobile phase flow-rate was $1 \mathrm{~mL} \mathrm{~min}^{-1}$ and the injection volume was $40 \mu \mathrm{L}$. Fluorescence detection (excitation and emission wavelengths 274 and $370 \mathrm{~nm}$, respectively) was used for detection of amisulpride and the IS.

\section{Optimization of SPE}

Solid-phase extraction (SPE) was chosen for sample preparation. This method enables simultaneous and rapid processing of many samples, cleaning extracts from biological material and concentration of determined compounds.

Oasis HLB cartridges were chosen for extraction of amisulpride and the internal standard from plasma samples. These cartridges contain adsorbent with both hydrophobic and hydrophilic properties. Preliminary sample extraction conditions were selected by using aqueous solutions the compounds investigated. The amisulpride and IS content of washings from the cartridge were determined after each stage of sample preparation (sorption, washing, and collection). Sample-preparation conditions were the same as those proposed by the cartridge manufacturer: conditioning (pre-washing) with $1 \mathrm{~mL}$ methanol then $1 \mathrm{~mL}$ water, washing with water and $30 \%(v / v)$ methanol-water, then collection by use of $1 \mathrm{~mL}$ methanol. Amisulpride and the IS were not found in the washing liquids after the adsorption and washing stages. The methanolic sample solution obtained in the collection stage was dried under vacuum and the residue was re-dissolved in $1.0 \mathrm{~mL}$ water-acetonitrile 75:25 $(v / v)$. The amisulpride and IS content were approximately 90 and $80 \%$, respectively, of the theoretical values (determined by analysis of solutions containing the compounds without the sample-preparation stage).

After development, sample extraction was performed on plasma containing known concentrations of analyte and IS. Endogenous plasma components did not interfere with the compounds of interest after their isolation by use of SPE. Pure acetonitrile, a mixture of equal volumes of acetonitrile and methanol, and double the volume of methanol were used as liquids for collection of amisulpride and IS but, because these solvents did not lead to more efficient extraction, $1 \mathrm{~mL}$ methanol was chosen for collection.

\section{Optimization of LC}

High-performance liquid chromatography with different methods of detection have been used for pharmacokinetic studies of amisulpride. We compared the sensitivity for amisulpride using the same chromatographic conditions but with application of diode-array and fluorescence detection. The DAD was set at the wavelength of maximum absorption, $274 \mathrm{~nm}$, and fluorescence detection was performed with excitation and emission wavelengths of 274 and $370 \mathrm{~nm}$, respectively. It was established that under similar chromatographic conditions fluorescence detection was six times more sensitive that UV detection. 
Table 1 Dependence of amisulpride retention on the amount of acetonitrile in the mobile phase

\begin{tabular}{lllll}
\hline $\begin{array}{l}\text { Amount of } \\
\text { acetonitrile }(\%)\end{array}$ & Component & $\begin{array}{l}\text { Retention } \\
\text { time }\end{array}$ & $k$ & Resolution \\
\hline 25 & AMS & 13.63 & 3.96 & 5.24 \\
\multirow{2}{*}{30} & IS & 16.92 & 5.15 & \\
& AMS & 10.28 & 2.74 & 5.08 \\
35 & IS & 12.77 & 3.64 & \\
& AMS & 8.97 & 2.26 & 4.78 \\
40 & IS & 11.10 & 3.04 & \\
& AMS & 7.98 & 1.90 & 4.35 \\
45 & IS & 9.74 & 2.54 & \\
& AMS & 7.35 & 1.67 & 3.94 \\
50 & IS & 8.84 & 2.16 & \\
& AMS & 7.05 & 1.57 & 3.69 \\
& IS & 8.41 & 2.06 & \\
\hline
\end{tabular}

$A M S$ amisulpride, $I S$ internal standard (metoclopramide)

Because the $\mathrm{CN}$ stationary phase used is more polar than $\mathrm{C}_{8}$ and $\mathrm{C}_{18}$ it enables faster separation with low mobile phase organic modifier content.

In bioanalysis, LC retention of the analytes should be sufficient to avoid interferences with the first peak in the chromatogram. For this reason, the effect of mobile phase $\mathrm{pH}$ on analyte retention was studied. Mobile phase $\mathrm{pH}$ tested was 6.0, 6.5, and 7.0. It was found that retention of amisulpride in this $\mathrm{pH}$ range did not vary significantly. Use of an acidic (pH 3.0) mobile phase, however, substantially reduced retention and resolution of amisulpride and the IS. Reduction of the acetonitrile content led to increased retention time and resolution of amisulpride and IS, but separation of the analyte from endogenous components of the plasma was not achieved. The $\mathrm{pH}$ eventually selected was 6.5 .

To achieve good retention of amisulpride and good resolution between amisulpride and IS the effect of the acetonitrile content of the mobile phase was studied. The retention time of amisulpride and amisulpride-IS resolution were determined using acetonitrile concentrations ranging from 25 to $50 \%(v / v)$. The retention times and resolution of the analytes decreased as the concentration of organic modifier was increased (Table 1). The final acetonitrile concentration selected was $35 \%(v / v)$.

\section{Results and Discussion}

\section{Validation}

The method was validated in accordance with USP 32 [17], International Conference of Harmonization (ICH) Guidelines [16, 18, 19], and other literature [20].

\section{Selectivity}

Selectivity is the ability of an analytical method to differentiate and quantify the analyte in the presence of other components of the sample; selectivity should be ensured at the lower limit of quantification (LLOQ). Six blank plasma samples from different sources were used for evaluation of method selectivity. Blank samples were tested for interference with the analyte and the IS. The selectivity criterion was that the maximum interference observed in blank plasma samples should not exceed one-fifth of the analyte response at the LLOQ [16].

Chromatograms obtained from blank human plasma, plasma spiked with amisulpride (10 $\mathrm{ng} \mathrm{mL}^{-1}$; LLOQ) and metoclopramide (IS, $1,000 \mathrm{ng} \mathrm{mL}^{-1}$ ) and from plasma spiked with amisulpride $\left(1,000 \mathrm{ng} \mathrm{mL}^{-1}\right.$; upper limit of quantification, ULOQ) and the IS are presented in Fig. 2, from which it apparent no interference was detected. The spectral purity of the peaks of amisulpride and the IS was, furthermore, monitored by use of the DAD and found to be more than $99 \%$ for both at the ULOQ level.

\section{Linearity}

The linearity of detector response was estimated by analysis of working standard solutions of amisulpride in the concentration range $20-2,000 \mathrm{ng} \mathrm{mL}^{-1}$. The dependence of detector response (peak area) on amisulpride concentration was described by the equation $Y=2060.3 C+$ 998.26, $r=0.9996$ (where $Y$ is peak area, $C$ is amisulpride concentration in $\mathrm{ng} \mathrm{mL}^{-1}$, and $r$ is the correlation coefficient).

The linearity of the method was evaluated by constructing a calibration plot in the range $10-1,000 \mathrm{ng} \mathrm{mL}^{-1}$ amisulpride in plasma by plotting the amisulprideto-internal standard peak-area ratio against amisulpride concentration. Least-squares linear regression analysis with the weighting coefficient $1 / C^{2}$ was used to determine the relationship between amisulpride concentration and detector response.

Each day the slope, intercept, and correlation coefficient were determined; results of these investigations are presented in Table 2 . The resulting calibration equation was $Y=(18.3 \pm 0.7) \times 10^{-4} C+(6 \pm 15) \times 10^{-4}$,

$r=0.9979$; the relationship between peak-area ratio and amisulpride concentration was linear within the concentration range studied.

The limit of detection (LOD) of amisulpride in plasma samples was $2 \mathrm{ng} \mathrm{mL}^{-1}$ (the serial dilution method was used; signal-to-noise ratio $=3$ ). The lowest limit of quantification (LLOQ) was defined as the lowest concentration in the linear region of the calibration plot for which the coefficient of variation $(\mathrm{CV})$ was reproducibly below 
Fig. 2 Chromatograms obtained from a Blank human plasma; b Plasma spiked at the LLOQ (10 $\mathrm{ng} \mathrm{mL}^{-1}$ amisulpride and $1,000 \mathrm{ng} \mathrm{mL}^{-1}$ metoclopramide (IS)); c Plasma spiked at the ULOQ

$\left(1,000 \mathrm{ng} \mathrm{mL}^{-1}\right.$ amisulpride and $1,000 \mathrm{ng} \mathrm{mL}^{-1}$ metoclopramide)
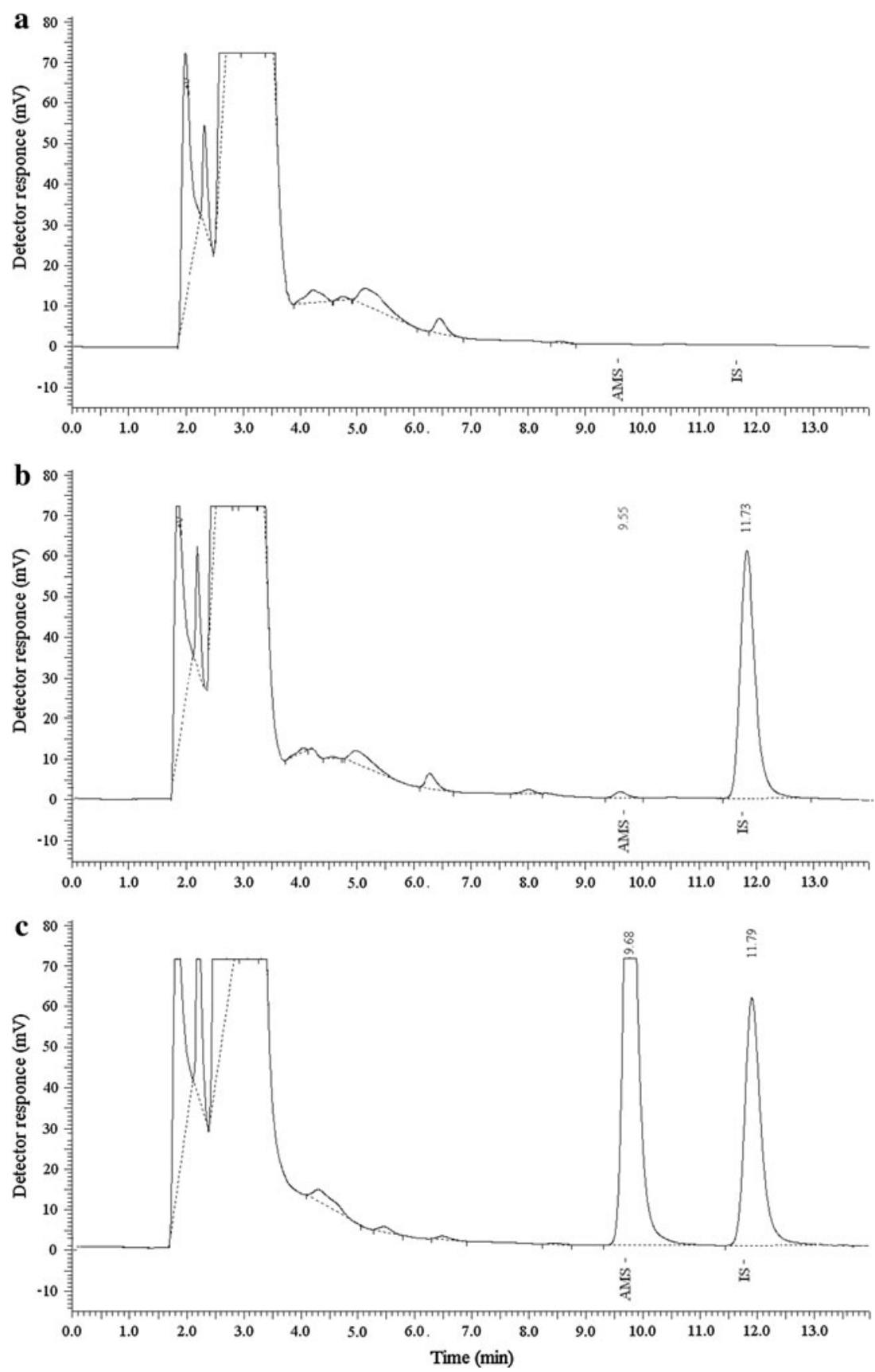

$20 \%$ and accuracy between 80 and 120\%. The average

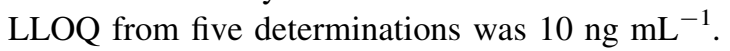

\section{Accuracy and Precision}

Accuracy and precision were determined by replicate analysis of samples with known amisulpride content. The mean value should be within $15 \%$ of the actual value [16, 20, 21]. The difference between mean amounts of amisulpride added and recovered (RE, \%) serves as a measure of accuracy. The coefficient of variation ( $\mathrm{CV}, \%)$, as a measure of precision at each concentration, should not exceed $15 \%$.
Intra-day and inter-day accuracy and precision were evaluated by analysis of quality-control samples containing amisulpride at three different concentrations-a low concentration (LQC), $30 \mathrm{ng} \mathrm{mL}^{-1}$, a concentration near the centre of the calibration plot (MQC), $300 \mathrm{ng} \mathrm{mL}^{-1}$, and a concentration near the upper limit of the calibration plot (HQC), $900 \mathrm{ng} \mathrm{mL}^{-1}$. Intra-day accuracy and precision were evaluated by analysis of these QC samples prepared and analyzed on 1 day (eight samples of each concentration; three replicate injections). Inter-day accuracy and precision were evaluated by analysis of these QC samples prepared and analyzed on five different days 
Table 2 Calibration plot data for amisulpride in human plasma

\begin{tabular}{llll}
\hline Day & Slope & Intercept & $r$ \\
\hline 1 & 0.001882 & -0.002320 & 0.9998 \\
2 & 0.001865 & -0.001105 & 0.9970 \\
3 & 0.001890 & -0.000968 & 0.9957 \\
4 & 0.001764 & -0.000368 & 0.9995 \\
5 & 0.001735 & 0.001759 & 0.9973 \\
Mean & 0.001827 & 0.000600 & 0.9979 \\
SD & $7.2 \times 10^{-5}$ & 0.001497 & 0.0018 \\
\hline
\end{tabular}

(three samples of each concentration; three replicate injections).

The dilution procedure for plasma samples containing amisulpride concentrations outside the calibration range was validated by analysis of eight diluted samples with an amisulpride concentration of $1,800 \mathrm{ng} \mathrm{mL}^{-1}(2 \times \mathrm{HQC})$, and evaluation of accuracy and precision from the results obtained.

The intra-day and inter-day precision and accuracy of the method are presented in Table 3. Intra-day precision ranged between 3.13 and $5.35 \%$ and inter-day precision was between 4.54 and $7.50 \%$. Intra-day accuracy was between -3.00 and $6.41 \%$ and inter-day accuracy was between 0.40 and $4.11 \%$. Precision and accuracy of analysis of diluted samples were also satisfactory.

All values for accuracy and precision were within the recommended limits.

\section{Recovery}

Recovery of amisulpride and the IS from plasma was determined at concentrations of 30,300, and $900 \mathrm{ng} \mathrm{mL}^{-1}$ for amisulpride and $1,000 \mathrm{ng} \mathrm{mL}^{-1}$ for metoclopramide by comparing peak areas obtained from plasma with those obtained from the same amounts of unextracted solutions [16]. Recovery was $94 \%$ for amisulpride and $95 \%$ for metoclopramide.
Stability

The stability of amisulpride in human plasma over three freeze-thaw cycles and during short-term, long-term, and post-preparative storage was tested by analysis of LQC (30 $\mathrm{ng} \mathrm{mL}{ }^{-1}$ ) and HQC (900 $\mathrm{ng} \mathrm{mL}^{-1}$ ) samples [16].

The freeze-thaw stability of the amisulpride was determined over three freeze-thaw cycles within 3 days. Spiked plasma samples were frozen at $-22{ }^{\circ} \mathrm{C}$ for $24 \mathrm{~h}$ and thawed at room temperature in each freeze-thaw cycle. To study short-term stability, the frozen $\left(-22{ }^{\circ} \mathrm{C}\right)$ and then thawed plasma samples were kept at room temperature for $6 \mathrm{~h}$ before sample preparation. The postpreparative stability of prepared plasma samples was studied after keeping the samples in the autosampler at $16{ }^{\circ} \mathrm{C}$ for $48 \mathrm{~h}$. The results obtained from these test samples were compared with those from freshly thawed and processed samples (reference samples).

Long-term stability was determined after keeping spiked plasma samples frozen at $-22{ }^{\circ} \mathrm{C}$ for 2 months. For this stability test the samples (test samples) were analyzed and the results were compared with those obtained from freshly prepared and processed samples (reference samples) [22].

The stability of amisulpride and metoclopramide (IS) in stock solutions was studied after storage at $2{ }^{\circ} \mathrm{C}$ for 1 month.

The results obtained from assessment of stability are given in Table 4. Three freeze-thaw cycles of the qualitycontrol samples did not seem to affect quantification of the amisulpride. Quality-control samples stored in a freezer at $-22{ }^{\circ} \mathrm{C}$ were stable for at least 2 months. Thawing of the frozen samples and keeping them at room temperature for $6 \mathrm{~h}$ had no effect on quantification. Prepared samples stored in autosampler at $16{ }^{\circ} \mathrm{C}$ were stable for at least $48 \mathrm{~h}$.

The stability of amisulpride and metoclopramide in stock solutions was confirmed after storage for 29 days at $2{ }^{\circ} \mathrm{C}$.

\section{Bioequivalence Study}

The applicability of the method was demonstrated in a randomized crossover bioequivalence study of two
Table 3 Intra-day $(n=8)$ and inter-day $(n=3 \times 5)$ precision and accuracy of LC analysis of amisulpride in QC samples

\begin{tabular}{llccc}
\hline $\begin{array}{l}\text { QC sample } \\
\left(\mathrm{ng} \mathrm{mL}^{-1}\right)\end{array}$ & $\begin{array}{l}\text { Dilution } \\
\text { factor }\end{array}$ & $\begin{array}{l}\text { Measured concentration } \\
\left(\mathrm{ng} \mathrm{mL}^{-1} ; \text { mean } \pm \mathrm{SD}\right)\end{array}$ & $\begin{array}{l}\text { Accuracy } \\
(\mathrm{RE}, \%)\end{array}$ & $\begin{array}{l}\text { Precision } \\
(\mathrm{CV}, \%)\end{array}$ \\
\hline $\begin{array}{l}\text { Intra-day } \\
30\end{array}$ & 1 & $29.2 \pm 1.0$ & -2.56 & 3.51 \\
300 & 1 & $319 \pm 17$ & 6.41 & 5.34 \\
900 & 1 & $893 \pm 28$ & -0.77 & 3.13 \\
1,800 & 2 & $1,746 \pm 93$ & -3.00 & 5.35 \\
Inter-day & & $30 \pm 2$ & & \\
30 & 1 & $309 \pm 16$ & 0.40 & 7.50 \\
300 & 1 & $937 \pm 41$ & 3.24 & 5.17 \\
900 & 1 & & 4.11 & 4.54 \\
\hline
\end{tabular}


Table 4 Results from testing of the stability of amisulpride in human plasma $(n=6)$

\begin{tabular}{|c|c|c|c|c|c|c|c|}
\hline \multirow[t]{2}{*}{ Stability test } & \multicolumn{3}{|l|}{ Test samples } & \multicolumn{3}{|l|}{ Reference samples } & \multirow{2}{*}{$\begin{array}{l}\text { Test/reference } \\
(\%)\end{array}$} \\
\hline & $\begin{array}{l}\text { Measured concentration } \\
\left(\mathrm{ng} \mathrm{mL} \mathrm{mL}^{-1} ; \text { mean } \pm \mathrm{SD}\right)\end{array}$ & $\begin{array}{l}\text { Accuracy } \\
\text { (RE, \%) }\end{array}$ & $\begin{array}{l}\text { Precision } \\
(\mathrm{CV}, \%)\end{array}$ & $\begin{array}{l}\text { Measured concentration } \\
\left(\mathrm{ng} \mathrm{mL} \mathrm{mL}^{-1} ; \text { mean } \pm \mathrm{SD}\right)\end{array}$ & $\begin{array}{l}\text { Accuracy } \\
\text { (RE, \%) }\end{array}$ & $\begin{array}{l}\text { Precision } \\
(\mathrm{CV}, \%)\end{array}$ & \\
\hline \multicolumn{8}{|l|}{ LQC level } \\
\hline Short-term & $27.8 \pm 0.4$ & -7.26 & 1.59 & $28.5 \pm 1.1$ & -5.00 & 3.96 & -2.38 \\
\hline Freeze-thaw & $27.7 \pm 1.1$ & -7.65 & 3.84 & $28.5 \pm 1.1$ & -5.00 & 3.96 & -2.79 \\
\hline Post preparative & $29.10 \pm 0.42$ & -3.01 & 1.43 & $28.5 \pm 1.1$ & -5.00 & 3.96 & 2.09 \\
\hline Long-term & $30.4 \pm 0.8$ & 1.35 & 2.66 & $31.3 \pm 0.6$ & 4.25 & 2.01 & -2.78 \\
\hline \multicolumn{8}{|l|}{ HQC level } \\
\hline Short-term & $829 \pm 33$ & -7.92 & 3.95 & $836 \pm 10$ & -7.14 & 1.18 & -0.85 \\
\hline Freeze-thaw & $845 \pm 11$ & -6.15 & 1.29 & $837 \pm 10$ & -7.14 & 1.18 & 1.06 \\
\hline Post preparative & $852 \pm 12$ & -5.38 & 1.31 & $836 \pm 10$ & -7.14 & 1.18 & 1.89 \\
\hline Long-term & $947 \pm 22$ & 5.19 & 2.31 & $972 \pm 7$ & 8.00 & 0.70 & -2.60 \\
\hline
\end{tabular}
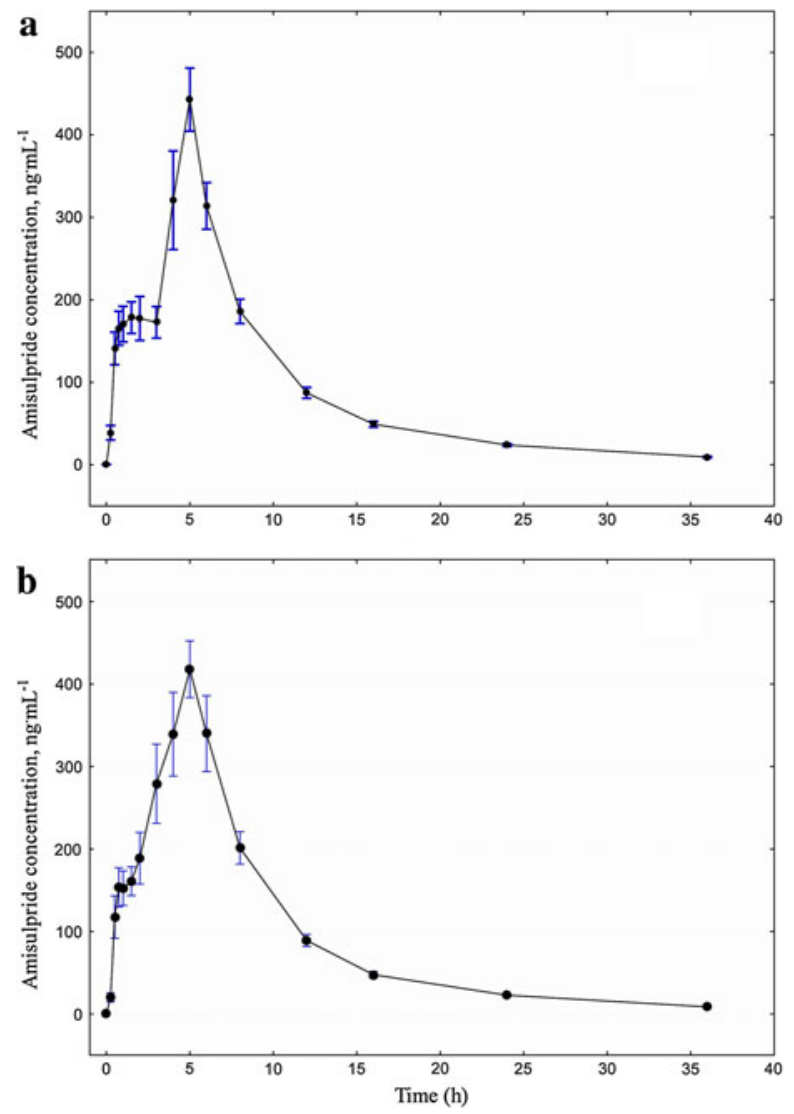

Fig. 3 Mean plasma concentration-time profiles of amisulpride for the test (a) and reference (b) preparations, obtained after administration of a single $200-\mathrm{mg}$ oral dose to 18 human volunteers

amisulpride preparations-Solian $200 \mathrm{mg}$ (Sanofi Winthrop Industrie, Gentille, France), used as the reference preparation, and Soleron 200 (Pharma Start, Kyiv, Ukraine) the investigated preparation.

Eighteen healthy volunteers (ten male and eight female), age $26-30$ years, weight $53-85 \mathrm{~kg}$, participated in the
Table 5 Mean $( \pm \mathrm{SD})$ pharmacokinetic data for two amisulpride preparations after administration of a single 200-mg oral dose to 18 human volunteers

\begin{tabular}{lcc}
\hline & Test preparation & Reference preparation \\
\hline$T_{\max }(\mathrm{h})$ & $4.8 \pm 0.8$ & $4.5 \pm 0.8$ \\
$C_{\max }\left(\mathrm{ng} \mathrm{mL}^{-1}\right)$ & $501 \pm 216$ & $515 \pm 208$ \\
$A U C_{0-36}\left(\mathrm{ng} \mathrm{h} \mathrm{mL}^{-1}\right)$ & $3,193 \pm 976$ & $3,311 \pm 1,144$ \\
$A U C_{0-\infty}\left(\mathrm{ng} \mathrm{h} \mathrm{mL}^{-1}\right)$ & $3,362 \pm 1,003$ & $3,483 \pm 1,137$ \\
$T_{1 / 2}(\mathrm{~h})$ & $7.4 \pm 2.2$ & $6.8 \pm 3.5$ \\
\hline
\end{tabular}

study. The subjects were underwent a clinical examination, electrocardiogram, and laboratory tests. The investigation was approved by the Ethics Committee and written informed consent was obtained from all the subjects. No volunteer took any drug for at least 14 days before the study or during it.

The volunteers were randomly divided into two groups of nine. The study was divided into two periods with a 6-day washout period. In the first period, group 1 received the reference preparation and group 2 received the test preparation. A crossover design was used in the study: in the second period, group 1 received the test preparation and group 2 the reference preparation.

A single oral dose of amisulpride (200 mg) was administrated under fasting conditions and serial blood samples were collected at suitable intervals up to $36 \mathrm{~h}$. Pharmacokinetic data including the area under the concentration-time curve during the sampling period $\left(A U C_{0-36}\right)$, the area under the concentration-time curve from zero to infinity $\left(A U C_{0-\infty}\right)$, and elimination half life $\left(T_{1 / 2}\right)$ were calculated by use of WinNonLin v. 5.2 (Pharsight, USA) pharmacokinetics software. The maximum plasma concentration $\left(C_{\max }\right)$ and the time to reach the peak plasma concentration $\left(T_{\max }\right)$ were obtained directly from the individual drug plasma concentration-time plots. 
A paired $t$ test was used for statistical evaluation of the data and all statistical calculations were defined at the level $P \leq 0.05$. Typical pharmacokinetic profiles (plasma concentration-time) for the two amisulpride preparations are presented in Fig. 3 and the main pharmacokinetic data are summarized in Table 5.

\section{Conclusion}

A simple, accurate, rapid, and selective reversed-phase LC method with fluorescence detection for analysis of amisulpride in human plasma after its isolation by solid-phase extraction has been developed and validated. A one-step solid-phase extraction procedure is proposed for preparation of plasma samples for analysis of amisulpride during pharmacokinetic investigations.

The sensitivity of the method (LLOD) was almost the same as that described in the literature for analogous pharmacokinetic studies, but in this method the amisulpride ULOQ was increased substantially — up to $1,000 \mathrm{ng} \mathrm{mL}^{-1}$ because the orally administered dose was increased to $200 \mathrm{mg}$ compared with $50 \mathrm{mg}$ investigated previously, and because of the need to perform pharmacokinetic investigations with this pharmaceutical preparation (Soleron 200).

The method was successfully applied to a bioequivalence study of two amisulpride preparations after oral administration of a 200-mg dose to eighteen healthy volunteers. It was demonstrated that both amisulpride preparations had similar pharmacokinetic properties.

Acknowledgments This work was supported by Pharma Start Ltd, (Kyiv, Ukraine), sponsor of the bioequivalence study of two amisulpride preparations (Solian $200 \mathrm{mg}$, Sanofi Winthrop Industrie S.A., Gentille, France and Soleron 200, Pharma Start, Kyiv, Ukraine).

Open Access This article is distributed under the terms of the Creative Commons Attribution Noncommercial License which permits any noncommercial use, distribution, and reproduction in any medium, provided the original author(s) and source are credited.

\section{References}

1. Coukell AJ, Spencer CM, Benfield P (1996) CNS Drugs 6:237-243
2. Costa JA, Silva E (1990) Ann Psychiatr 5:242-256

3. Agnoli A, Ravizza L, Torta R (1989) In: Proc 37th Italian Psychiatry Society Congress, Rome, 6-11 February 1989, CIC International, Rome

4. Josserand F, Weber F (1988) Ann Psychiatr 3:306-312

5. Noble S, Benfield P (1999) CNS Drugs 12:471-477

6. Hamon-Vilcot B, Chaufour S, Deschamps C, Canal M, Zieleniuk I, Ahtoy P, Chretien P, Rosenzweig P, Nasr A, Piette F (1998) Eur J Clin Pharmacol 54:405-415

7. Kamizono A, Inotsume N, Miyamote K, Ueda K, Miyakawa T, Arimoto H, Nakano M (1991) J Chromatogr B 567:113-119

8. Mokrim R, Brunet C, Cazin M, Gressier B, Luyckx M, Dine T, Robert H, Cazin JC (1993) Methods Find Exp Clin Pharmacol 15:41-50

9. Frahnert C, Rao ML, Grasmäder K (2003) J Chromatogr B 794:35-40. doi:10.1016/S1570-0232(03)00393-3)

10. Sachse J, Härtter S, Weigmann H, Hiemke C (2003) J Chromatogr B 784:405-411. doi:10.1016/S1570-0232(02)00808-5

11. Pehourcq F, Ouariki S, Begaud B (2003) J Chromatogr B 789:101-117. doi:10.1016/S1570-0232(03)00045-X

12. Kirchherr H, Kühn-Velten WN (2006) J Chromatogr B 843:100-105. doi:10.1016/j.jchromb.2006.05.031

13. Gschwend MH, Arnold P, Ring J, Martin W (2006) J Chromatogr B 831:132-140. doi:10.1016/j.jchromb.2005.11.042

14. Malavasi B, Locatell M, Ripamonti M, Ascalone V (1996) J Chromatogr B 676:107-112

15. Ascalone V, Ripamonti M, Malavasi B (1996) J Chromatogr B 676:95-101

16. Guidance for industry, bioanalytical method validation. US Department of Heaths and Human Services, Food and Drug Administration, Center for Drug Evaluation and Research (CDER), Rockville, MD, 2001. http://www.fda.gov/Drugs/ GuidanceComplianceRegulatoryInformation/Guidances/ucm064 964.htm

17. United States Pharmacopoeia 32/National Formulary 27 (2009) United State Pharmacopoeial Convention. Rockville, MD, pp 733-740

18. International Conference of Harmonization, Q2A: Text on validation of analytical procedures. (1995) US FDA Federal Register, V. 60 , March, pp 11260-11273

19. International Conference of Harmonization, Q2B: Validation of analytical procedures: methodology. (1997) US FDA Federal Register, V. 62, May, pp 27463-27495

20. Bansal S, DeStefano A (2007) AAPS J 9:109-115. doi:10.1208/ aapsj0901011

21. Viswanathan C, Bansal S, Booth B, DeStefano A, Rose M, Sailstad J, Shah V, Skelly J, Swann P, Weiner R (2007) AAPS J 9:30-38. www.aapsj.org (doi:10.1208/aapsj0901004)

22. Nowatzke W, Woolf E (2007) AAPS J 9:117-122. doi:10.1208/ aapsj0902013 